\title{
PERSONAL HYGIENE EDUCATION SAAT MENSTRUASI SOLUSI PENINGKATAN KUALITAS HIDUP REMAJA DI MASA DEPAN
}

\author{
Nuryaningsih"1), Heri Rosyati ${ }^{11}$, Afra Hadiyani ${ }^{1)}$, Syafira Nurfajri Istiqomah ${ }^{1)}$ \\ ${ }^{1)}$ Fakultas Kedokteran dan Kesehatan, Universitas Muhammadiyah Jakarta, Tangerang Selatan, Banten, Indonesia \\ Coresponding author: Nuryaningsih \\ E-mail: nuryaningsih@umj.ac.id
}

Diterima 30 November 2021, Direvisi 03 Desember 2021, Disetujui 03 Desember 2021

\begin{abstract}
ABSTRAK
Personal hygiene saat menstruasi menentukan kualitas hidup remaja puteri dimasa depan. Remaja puteri sangat rentan terkena infeksi pada organ reproduksi terutama saat menstruasi. Kondisi ini menuntut remaja puteri mendapatkan informasi yang tepat dan benar tentang personal hygiene saat menstruasi. Personal Hygiene Education saat menstruasi merupakan suatu kegiatan pemberian pendidikan kesehatan tentang upaya memelihara kesehatan diri terutama saat menstruasi. Tujuan Pengabdian Kepada Masyarakat ini yaitu meningkatkan pengetahuan tentang cara membersihkan organ reproduksi ketika menstruasi pada orang tua siswa SDN 05 Marunda Kelas 6, Cilincing, Jakarta Utara. Metode yang dilakukan pada kegiatan Pengabdian Kepada Masyarakat ini yaitu dengan menyebarkan kuesioner sebelum (pre test), pelaksanaan personal hygiene education saat menstruasi dan sesudah kegiatan (post test) sebagai bentuk evaluasi. Hasil pre test menunjukkan $6,7 \%$ orang tua kurang memahami cara melakukan personal hygiene saat menstruasi dan hasil post test menunjukkan peningkatan pengetahuan orang tua menjadi $86,7 \%$ tentang personal hygiene saat menstruasi. Kegiatan ini sangat didukung untuk dapat dilaksanakan secara berkelanjutan.
\end{abstract}

Kata kunci: personal hygiene education saat menstruasi; sumber informasi; pengetahuan

\begin{abstract}
Personal hygiene during menstruation determines the quality of life of young women in the future. Teenage girls are very susceptible to infection in the reproductive organs, especially during menstruation. This condition requires young women to get the right and correct information about personal hygiene during menstruation. Personal Hygiene Education during menstruation is an activity to provide health education on maintaining personal health, especially during menstruation. The purpose of this community service is to raise knowledge about how to clean the reproductive organs during menstruation for parents of grade 6 students at SDN 05 Marunda, Cilincing, North Jakarta. The method used in this community service activity is by distributing questionnaires before (pre-test), implementing personal hygiene education during menstruation, and after activities (post-test) as a form of evaluation. The results of the pre-test showed that $6,7 \%$ of parents did not understand how to do personal hygiene during menstruation. Meanwhile, the results of the post-test showed an increase in the knowledge of parents to $86,7 \%$ about personal hygiene during menstruation. This activity is strongly suggested to be carried out sustainably.
\end{abstract}

Keywords: personal hygiene education during menstruation; source of information; knowledge

PENDAHULUAN

Personal hygiene saat menstruasi menentukan status kesehatan reproduksi remaja dimasa yang akan datang. Masa remaja (10-24 tahun) merupakan masa transisi dari anak-anak menuju dewasa dan masa kritis yang memiliki banyak perubahan. Perubahan yang berlangsung pada remaja dapat meliputi pubertas, meningkatnya penalaran logis, meningkatnya pemikiran idealistis, dan egosentris, harapan yang menyimpang, perubahan yang berlangsung di sekolah, teman-teman sebaya, persahabatan, pacaran dan perubahan menuju kemandirian. Khusus pada remaja puteri merupakan masa tumbuh kembang dan awal terjadinya perubahan fisik pubertas termasuk adanya menstruasi pertama kali (menarche). Remaja puteri sangat rentan terkena infeksi organ reproduksi saat mengalami menstruasi (Nugraheni and Indarjo, 2018). Kondisi rentan ini dapat berakibat morbiditas dan komplikasi bagi remaja yang mengabaikan personal hygiene saat menstruasi (Kinanti, 2009). Terjadinya kanker serviks dan gangguan kesehatan reproduksi lainnya merupakan salah satu dampak dari personal hygiene yang buruk (Aniebue, Aniebue and Nwankwo, 2009). Hal ini 
mengindikasikan personal hygiene saat menstruasi sejak masa remaja penting dilakukan terutama di usia Sekolah Dasar.

Personal Hygiene Education merupakan suatu kegiatan pemberian pendidikan kesehatan tentang upaya memelihara kesehatan diri terutama saat menstruasi. Edukasi berisi tentang personal hygiene organ reproduksi, memberikan pengetahuan tentang cara membersihkan organ reproduksi yang benar ketika menstruasi sehingga dapat berperilaku Hidup Bersih dan Sehat. Personal hygiene saat menstruasi yang buruk dapat disebabkan karena pengetahuan yang kurang tentang pentingnya menjaga kesehatan organ reproduksi saat menstruasi. Hasil survei pendahuluan di Puskesmas Rumah Susun (Rusunawa) Marunda, Cilincing, Jakarta Utara pada siswa SDN 05 Marunda Kelas 6 menunjukkan sebesar $48 \%$ memiliki pengetahuan kurang tentang personal hygiene saat menstruasi (Nuryaningsih and Rosyati Heri, 2020).

Edukasi tentang Personal hygiene saat menstruasi sangat diperlukan remaja puteri mengingat kebersihan organ reproduksi sangat berpengaruh terhadap kesehatan reproduksi remaja. Pengetahuan remaja puteri erat pula dengan akses sumber informasi dalam mendapatkan pengetahuan tentang personal hygiene saat menstruasi. Sumber-sumber informasi mempunyai pengaruh terhadap pengetahuan kesehatan reproduksi remaja puteri. Semakin banyak sumber informasi yang diperoleh oleh siswi semakin baik pula pengetahuan tentang Personal Hygiene saat menstruasi, begitupula sebaliknya. Pengetahuan umumnya datang dari pengalamam, juga bisa didapat dari informasi yang disampaikan oleh guru, orang tua, teman, buku dan surat kabar.

Hasil penelitian tentang hubungan sumber informasi dengan pengetahuan Personal hygiene saat menstruasi menemukan sumber informasi yang didapatkan siswi SD kelas 6 sebagian besar berasal dari ibu (86\%), kakak $(7 \%)$, nenek $(4,7 \%)$ dan media cetak $(2,3 \%)$ (Nuryaningsih and Rosyati Heri, 2020).

Salah satu tugas perkembangan yang penting di masa remaja yaitu pengembangan kemampuan mandiri yang terjadi secara bertahap untuk mengambil keputusan. Pada tahap ini peran orang tua sangat strategis sebagai manager yang efektif dalam membantu remaja terhindar dari pengambilan keputusan yang berisiko termasuk dalam memelihara personal hygiene saat menstruasi. Pemberian edukasi kepada orang tua dianggap akan efektif dalam upaya peningkatan kualitas hidup remaja di masa depan. Orang tua diharapkan dapat melakukan peran pendampingan kepada puterinya ketika mengalami menstruasi terlebih saat pertama kali mendapatkan menstruasi (menarche).

Adapun tujuan dari kegiatan Pengabdian Kepada Masyarakat ini untuk meningkatkan pengetahuan orang tua siswi SDN 05 Marunda, Cilincing Jakarta Utara tentang personal hygiene saat menstruasi agar orang tua dapat memberikan informasi yang benar dan tepat pada puterinya sehingga status kesehatan reproduksi serta kualitas hidup remaja puteri di masa depan lebih optimal.

\section{METODE}

Pelaksanaan Pengabdian Kepada Masyarakat ini dilakukan kepada orang tua siswi SDN 05 Marunda kelas 6 di Ruang Aula SDN 05 Marunda, Cilincing, Jakarta Utara yang diikuti 30 peserta, pada tanggal 15 Juni 2021. Pemberian edukasi ini dilakukan dengan metode tatap muka langsung dengan protokol kesehatan Covid-19 secara ketat. Pelaksanaan Pengabdian Masyarakat ini selain dihadiri oleh Kepala sekolah SDN 05 Marunda juga didampingi bidan Koordinator Unit Kesehatan Masyarakat (UKM) dan Petugas Ketuk Pintu Layani Dengan Hati (KPLDH) yang mengani Usaha Kesehatan Sekolah (UKS).

Personal Hygiene saat menstruasi termasuk dalam ruang lingkup Kesehatan Reproduksi Remaja (KRR) yang termasuk dalam program UKS yang merupakan bagian dari usaha kesehatan pokok yang menjadi tugas Puskesmas termasuk Puskesmas Rusunawa Marunda, Jakarta Utara. Dalam upaya pembinaan dan pengembangan UKS terdapat tiga program pokok yaitu pendidikan kesehatan bagi remaja, pelayanan kesehatan bagi remaja dan pembinaan lingkungan sehat (DKI Jakarta, 2020)

Pengabdian Kepada Masyarakat ini dilakukan dengan beberapa tahap dimulai dari survei lokasi dan perijinan untuk melakukan kegiatan pengabdian di sekolah tersebut. Sekolah Dasar Negeri (SDN) 05 Marunda terletak di kawasan Rumah Susun (Rusunawa) Marunda yang beralamat di Jalan Rusunawa Marunda, RT.2/RW.7, Marunda, Cilincing, Jakarta Utara. SDN 05 Marunda termasuk SD yang menjadi wilayah kerja Puskesmas Rusunawa Marunda yang berlokasi di dalam kawasan Rumah susun sewa Marunda yang beralamat di Cluster B Blok 8, Kelurahan Marunda, Kecamatan Cilincing, Jakarta Utara (DKI Jakarta, 2020).

Pada tahap pelaksanaan edukasi diawali dengan pengukuran pengetahuan orang tua dengan pengisian kuesioner sebelum edukasi (pre-test). Kegiatan dilanjutkan dengan 
pemberian edukasi personal hygiene saat menstruasi berupa penyuluhan dan pembagian leaflet kepada peserta. Tujuan pemberian leaflet ini agar informasi tentang Personal Hygiene saat menstruasi tersebar luas sehingga dapat diketahui oleh orang banyak termasuk keluarga, sahabat, tetangga dan remaja puteri yang lain.

Kegiatan Pengabdian Kepada Masyarakat ini berjalan secara interaktif dengan tanya jawab dan antusiasme dari peserta. Kegiatan diakhiri dengan pembagian kuesioner (post-test) sebagai evaluasi tingkat . pengetahuan orang tua siswi SDN 05 Marunda Kelas 6 sebelum dan sesudah diberikan edukasi personal hygiene saat menstuasi.

\section{HASIL DAN PEMBAHASAN}

Karakteristik peserta personal hygiene education dapat dilihat pada tabel dibawah ini:

Tabel 1. Karakteristik peserta Personal Hygiene Education

\begin{tabular}{|c|c|c|}
\hline Karakteristik & $\mathrm{N}=\mathbf{3 0}$ & $\%$ \\
\hline \multicolumn{3}{|l|}{ Orang tua } \\
\hline Ayah & 7 & 23,3 \\
\hline Ibu & 23 & 76,7 \\
\hline \multicolumn{3}{|l|}{ Usia } \\
\hline \multicolumn{3}{|l|}{ Ayah } \\
\hline $30-49$ tahun & 6 & 85,7 \\
\hline$\geq 50$ tahun & 1 & 14,3 \\
\hline \multicolumn{3}{|l|}{ Ibu } \\
\hline $30-49$ tahun & 22 & 95,7 \\
\hline$\geq 50$ tahun & 1 & 4,3 \\
\hline \multicolumn{3}{|l|}{ Pendidikan } \\
\hline \multicolumn{3}{|l|}{ Ayah } \\
\hline SD & 1 & 14,3 \\
\hline SMP & 3 & 42,9 \\
\hline SMA & 2 & 28,5 \\
\hline PT & 1 & 14,3 \\
\hline \multicolumn{3}{|l|}{ Ibu } \\
\hline SD & 2 & 8,7 \\
\hline SMP & 15 & 65,2 \\
\hline SMA & 5 & 21,7 \\
\hline PT & 1 & 4,4 \\
\hline \multicolumn{3}{|l|}{ Pekerjaan } \\
\hline \multicolumn{3}{|l|}{ Ayah } \\
\hline Tidak Bekerja & 1 & 14,3 \\
\hline Pedagang & 1 & 14,3 \\
\hline Buruh & 1 & 14,3 \\
\hline Nelayan & 3 & 42,8 \\
\hline Pegawai Swasta & 1 & 14,3 \\
\hline \multicolumn{3}{|l|}{ Ibu } \\
\hline Ibu Rumah Tangga & 16 & 69,5 \\
\hline Pedagang & 4 & 17,4 \\
\hline Buruh & 2 & 8,7 \\
\hline Pegawai Swasta & 1 & 4,4 \\
\hline
\end{tabular}

Hasil kegiatan Pengabdian Kepada Masyarakat tentang informasi karakteristik peserta personal hygiene education saat menstruasi berdasarkan Tabel 1 pada orang tua yang mendominasi yaitu ibu $(76,7 \%)$, usia $30-49$ tahun $(95,7 \%)$, pendidikan SMP $(65,2 \%)$, pekerjaan ibu Rumah Tangga $(69,5 \%)$ peserta orang tua ayah uSIA tertinggi 30-49 tahun $(85,7 \%)$, pendidikan SMP $(42,9 \%)$, pekerjaan nelayan $(42,8 \%)$.

Peserta Pengabdian Kepada Masyarakat yang hadir sebagian besar adalah ibu. Hal ini dimungkinkan kesibukan ayah mencari nafkah dan kegiatan diluar rumah yang mengharuskan ibu lebih berperan dalam mengurus rumah tangga dan anak-anak termasuk remaja puterinya. Karakteristik peserta (ayah dan ibu) sebagian besar memiliki usia diantara 30-49 tahun mengindikasikan orang tua siswi SDN 05 Marunda Kelas 6 masih termasuk usia produktif. Pengertian usia produktif adalah usia ketika seseorang masih mampu bekerja dan menghasilkan sesuatu (KBBI Online, 2021).

Sebagian besar orang tua siswi SDN 05 Marunda Kelas 6 berpendidikan SMP, yang menunjukkan berada ditingkat menengah. Hal ini berkaitan dengan penyampaian informasi yang diberikan. Penyampaian informasi sangat erat dengan teknik berkomunikasi yang baik. Komunikasi dipengaruhi oleh beberapa faktor. Faktor tersebut diantaranya penyampaian pesan, situasi, kondisi, media dan tujuan pesan (Effendy, 2011).

Pada karekteristik pekerjaan, orang tua siswi SDN 05 Marunda Kelas 6, yaitu sebagian besar pekerjaan ibu adalah ibu Rumah Tangga yang memungkinkan memiliki waktu luang yang lebih banyak untuk remaja puterinya. Ibu dapat mengatur aktivitas pekerjaan rumah remaja serta dapat berpartisipasi aktif dalam petemuan antara orang tua dan guru termasuk hadir dalam kegiatan edukasi personal hygiene saat menstruasi.

Pekerjaan ayah siswi SDN 05 Marunda Kelas 6 sebagian besar adalah nelayan. Hal ini dimungkinkan karena faktor geografis dari wilayah kelurahan Marunda berbatasan dengan laut Jawa di sebelah utara, Cilincing disebelah barat, Kabupaten Bekasi di sebelah timur dan Rorotan di sebelah selatan (Wikipedia, 2021).

Tabel 2. Pengetahuan Orang tua tentang Personal Hygiene saat Menstruasi

\begin{tabular}{lcccc}
\hline Pengetahuan & \multicolumn{4}{c}{$\mathbf{N}=\mathbf{3 0}$} \\
\cline { 2 - 5 } & $\begin{array}{l}\text { Pre } \\
\text { Test }\end{array}$ & $\%$ & $\begin{array}{l}\text { Post } \\
\text { Test }\end{array}$ & $\%$ \\
$\begin{array}{l}\text { Ayah } \\
\text { Definisi Personal } \\
\text { menstruasi }\end{array}$ & Hygiene & Saat \\
$\begin{array}{l}\text { Benar } \\
\text { Salah }\end{array}$ & 1 & 14,3 & 5 & 71,4 \\
\hline & 6 & 85,7 & 2 & 28,6 \\
\hline
\end{tabular}




\begin{tabular}{|c|c|c|c|c|}
\hline \multirow{2}{*}{$\begin{array}{l}\text { Perilaku } \\
\text { menstruasi } \\
\text { Benar }\end{array}$} & \multirow{2}{*}{$\begin{array}{c}\text { Personal } \\
0\end{array}$} & \multicolumn{2}{|c|}{ Hygiene } & \multirow{2}{*}{$\begin{array}{l}\text { saat } \\
85,7\end{array}$} \\
\hline & & 0 & 6 & \\
\hline Salah & 7 & 100 & 1 & 14,3 \\
\hline \multicolumn{5}{|l|}{ Ibu } \\
\hline $\begin{array}{l}\text { Definisi } \\
\text { menstruasi }\end{array}$ & Personal & \multicolumn{2}{|c|}{ Hygiene } & Saat \\
\hline Benar & 2 & 8,7 & 22 & 95,6 \\
\hline Salah & 21 & 91,3 & 1 & 4,4 \\
\hline $\begin{array}{l}\text { Perilaku } \\
\text { menstruasi }\end{array}$ & Personal & \multicolumn{2}{|c|}{ Hygiene } & saat \\
\hline Benar & 3 & 13 & 21 & 91,3 \\
\hline Salah & 20 & 87 & 2 & 8,7 \\
\hline
\end{tabular}

Berdasarkan tabel 2 pengetahuan orang tua sebelum dilakukannya edukasi (pre test) yang mengetahui definisi Personal Hygiene saat menstruasi pada ayah yaitu $14,3 \%$, ibu yaitu $8,7 \%$, sedangkan yang mengetahui perilaku Personal Hygiene saat menstruasi hanya ditemukan pada ibu yaitu $13 \%$.

Pengetahuan orang tua setelah dilakukan edukasi (post test) yang mengetahui definisi Personal Hygiene saat menstruasi pada ayah mengalami peningkatan menjadi $71,4 \%$, ibu yaitu $95,6 \%$, sedangkan yang mengetahui perilaku Personal Hygiene saat menstruasi pada ayah yaitu $85,7 \%$ sedangkan pada ibu yaitu $91,3 \%$.

Pengetahuan menyangkut ingatan tentang ide, benda atau fenomena. Orang yang mempunyai pengetahuan menyimpan ide, fenomena tersebut dalam ingatannya dan sanggup menggunakannya sewaktu-waktu jika diperlukan (Lapau B, 2012). Pengetahuan personal hygiene yang dimaksud yaitu definisi personal hygiene saat menstruasi dan perilaku personal hygiene saat menstruasi.

Mengawasi remaja secara efektif merupakan salah satu aspek penting dari peran orang tua. Pengawasan penting yang dapat dilakukan orang tua ketika anak-anak memasuki masa remaja diantaranya pendampingan remaja saat melalui masa-masa pubertas. Orang tua dapat berperan dalam menemukan informasi, membantu membuat, mengelola kontak sosial dengan teman-teman sebaya dan orang dewasa lainnya, membantu membangun pilihan-pilihan serta memberikan bimbingan.

Keterlibatan ayah dan ibu ketika remaja menghadapi masa pubertas memberikan peluang terselesaikannya masalah-masalah pubertas dengan baik. Keterlibatan bersama antara ayah dan ibu serta saling menghargai diharapkan dapat membantu remaja puteri dalam mengembangkan sikap positifnya terhadap perilaku hidup bersih dan sehat termasuk memelihara Personal hygiene saat menstruasi.
Keterbatasan pengetahuan dan informasi yang dimiliki ayah, rasa tabu serta faktor kedekatan dengan ayah memungkinkan tidak terjadinya transfer informasi dari ayah kepada puterinya. Kegiatan dan kesibukan ayah diluar rumah memungkinkan menjadi pemicu ayah tidak termasuk sumber informasi yang berpotensi memberikan informasi personal hygiene saat menstruasi pada remaja puterinya.

Sejak bayi hingga masa remaja, dibandingkan ayah, ibu lebih memiliki keterlibatan besar dalam pengasuhan anak termasuk pemberian informasi. Ibu merupakan sumber informasi yang paling utama tentang personal hygiene saat menstruasi (Marván and Molina-Abolnik, 2012). Penelitian di Nepal menjelaskan bahwa ibu merupakan salah satu dari pilihan sumber informasi terbaik untuk meningkatkan personal hygiene saat menstruasi pada perempuan atau remaja puteri yang berkebutuhan khusus. (Mahat, Parajuli and Pokhrel, 2020).

Remaja puteri percaya bahwa ibu adalah sumber informasi dan pendukung terbaik selama masa pubertas tetapi hanya sedikit yang menggambarkan pengalaman yang baik tentang komunikasi dalam prakteknya. Semakin sering remaja puteri memperoleh informasi tentang materi-materi menstruasi melalui komunikasi dalam keluarga khususnya orang tua terutama ibu maka personal hygiene saat menstruasi akan lebih baik pula (Crichton, Ibisomi and Gyimah, 2012).

Ayah dan ibu sebagai sumber informasi bagi remaja puteri harus mendapatkan informasi yang benar dan tepat serta peningkatan pengetahuan tentang personal hygiene saat menstruasi sehingga tujuan dari informasi dapat tersampaikan dan tercapai.

Tabel 3. Pengetahuan Orang tua Tentang Personal Hygiene Education

\begin{tabular}{|c|c|c|c|c|}
\hline \multirow{2}{*}{$\begin{array}{l}\text { Pengetahuan } \\
\text { Orang tua }\end{array}$} & \multicolumn{4}{|c|}{$\mathrm{N}=\mathbf{3 0}$} \\
\hline & $\begin{array}{l}\text { Pre } \\
\text { Test }\end{array}$ & $\%$ & $\begin{array}{l}\text { Post } \\
\text { Test }\end{array}$ & $\%$ \\
\hline Baik & 2 & 6,7 & 26 & 86,7 \\
\hline Kurang & 28 & 93,3 & 4 & 13,3 \\
\hline
\end{tabular}

Berdasarkan Tabel 3 pengetahuan orang tua siswi SDN 05 Marunda Kelas 6 tentang personal hygiene saat menstruasi mengalami peningkatan sebelum mendapatkan edukasi (pre test) yaitu $6,7 \%$ menjadi $86,7 \%$ setelah dilakukan eduksi (post test).

Pemberian informasi dan edukasi secara langsung memperlihatkan perubahan pengetahuan orang tua tentang personal hygiene saat menstruasi menjadi lebih baik. 


\section{Edukasi tentang Personal Hygiene Menstruasi \\ Kegiatan edukasi dilakukan selama 3 jam dan} diikuti oleh 30 orang tua siswi SDN 05 Marunda Kelas 6 sebagai peserta. Kegiatan dibuka oleh sambutan Kepala Sekolah SDN 05 Marunda, Cilincing, Jakarta Utara dan sambutan Bidan Koordinator Unit Kesehatan Masyarakat (UKM) (Gambar 1.).

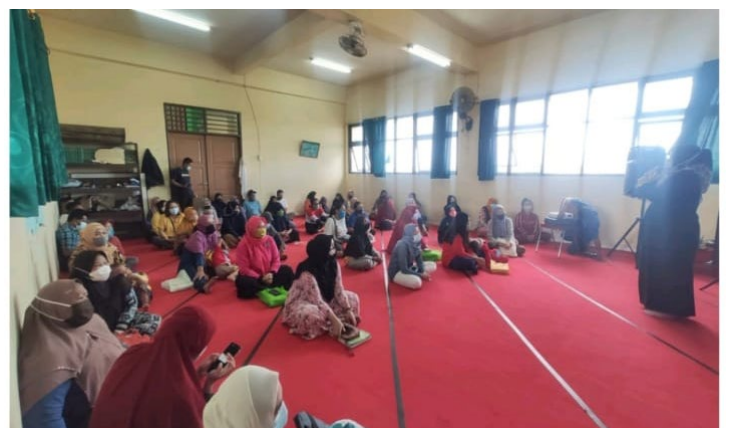

Gambar 1. Pembukaan Kegiatan Pengabdian Kepada Masyarakat

Materi edukasi yang diberikan berupa presentasi interaktif tentang pengertian menstruasi, personal hygiene saat menstruasi, prilaku personal hygiene saat menstruasi, aturan penggunaan pembalut, pembuangan pembalut, dampak negatif tidak menjaga personal hygiene saat menstruasi. Akhir sesi edukasi dilakukan diskusi interaktif melalui tanya jawab dari peserta (Gambar 2.)

Materi yang disampaikan juga meliputi kerugian tidak menjaga personal hygiene saat menstruasi. Edukasi ini memberikan gambaran pentingnya sumber informasi yang benar tentang personal hygiene saat menstruasi.

Hasil penelitian di Nepal menemukan sebagian besar dari perempuan berkebutuhan khusus memiliki praktik personal hygiene saat menstruasi yang tidak tepat seperti mandi hanya pada hari keempat menstruasi, membersihkan alat kelamin dengan sabun dan air dan menggunakan teknik pembersihan yang salah (Mahat, Parajuli and Pokhrel, 2020)

Hal penting yang perlu diperhatikan dalam personal hygiene saat menstruasi adalah mencuci alat kelamin dengan air bersih, menggunakan celana dalam yang menyerap keringat, sering mengganti celana dalam minimal $2 x /$ hari atau jika lembab, sering mengganti pembalut ketika penuh atau tidak lebih dari 4 jam, mandi minimal 2x/hari, membersihkan vagina/kelamin dengan air mengalir dari arah depan kebelakang dan mengeringkan alat kelamin/vagina setelah dibasuh air mengalir dengan handuk lembut atau tisu.

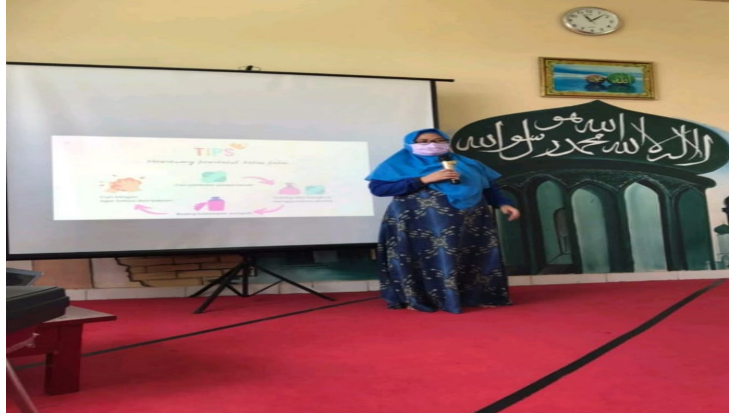

Gambar 2. Presentasi materi Personal Hygiene saat menstruasi

Pemberian materi tentang cara membersihkan alat kelamin, aturan penggunaan dan pembuangan pembalut yang benar juga menjadi informasi yang paling ditanyakan oleh orang tua (Gambar 3.)

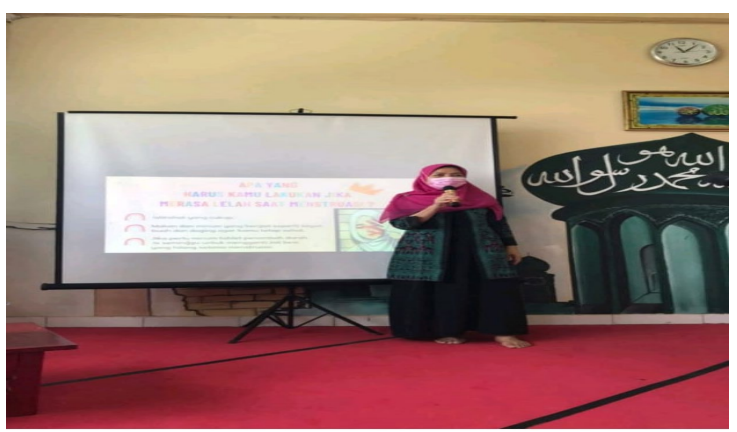

Gambar 3. Presentasi aturan penting penggunaan pembalut

Beberapa aturan penting seputar pembalut diantaranya tips membuang pembalut yaitu mencuci pembalut sampai bersih, menggulung dan membungkus pembalut menggunakan plastik, membuang ke tempat sampah, mencuci tangan sebelum dan sesudah mencuci pembalut.

Materi edukasi juga membahas sedikit tentang mengatasi kelelahan ketika mengalami menstruasi yaitu dengan istirahat yang cukup, makan dan minum yang bergizi seperti sayur, buah, daging dan meminum tablet penambah darah1x/minggu untuk mengganti zat besi yang hilang saat menstruasi

Orang tua sebagai peserta Pengabdian Kepada Masyarakat menyadari pentingnya informasi yang telah diberikan bagi puteri-puteri mereka yang sudah dan akan mengalami menstruasi dan menyimak serta fokus bertanya tentang materi yang disampaikan (Gambar 4.) 


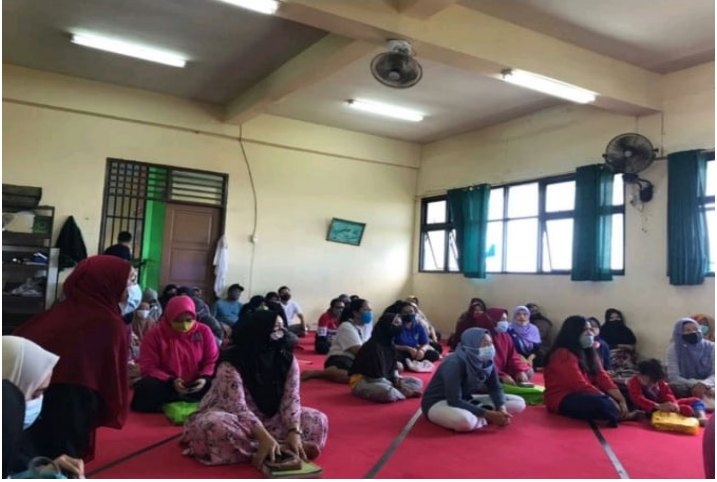

Gambar 4. Peserta menyimak dan bertanya

Penyebaran leaflet juga digunakan sebagai media informasi untuk memudahkan menyebaran informasi personal hygiene saat menstruasi kepada banyak orang (Gambar 5.).

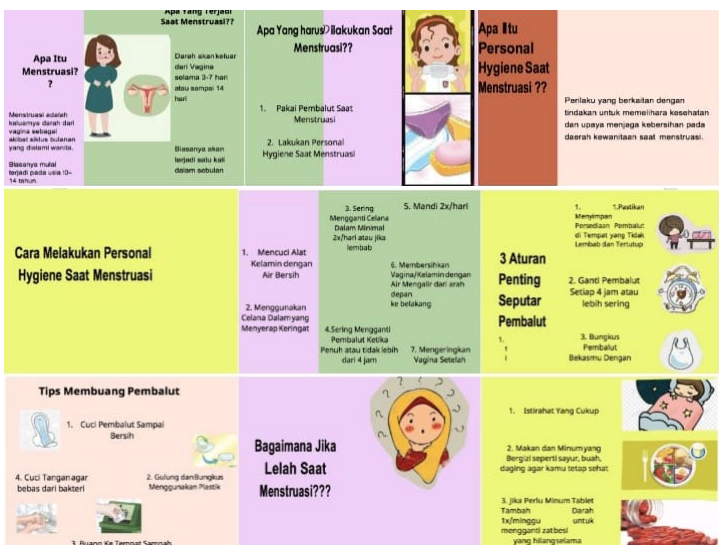

Gambar 5. Leaflet Personal Hygiene saat menstruasi

\section{SIMPULAN DAN SARAN}

Tingkat pengetahuan orang tua siswi SDN 05 Marunda, Cilincing, Jakarta Utara Kelas 6 tentang Personal Hygiene saat menstruasi masih kurang. Namun setelah diberikan edukasi, tingkat pengetahuan orang tua sebagai peserta meningkat sangat signifikan.

Peserta orang tua merasakan manfaat dari edukasi yang diberikan tentang pentingnya personal hygiene saat menstruasi bagi anakanak perempuannya yang baru menginjak dewasa. Adanya peningkatan pengetahuan orang tua tentang personal hygiene saat menstruasi diharapkan dapat berperan sebagai "change agent" dan sumber informasi yang benar dan tepat bagi remaja puteri dalam mengaplikasikan personal hygiene saat menstruasi sehingga kualitas hidup remaja putri dapat terjamin.

Keterlibatan orang tua sebagai sumber informasi dan pendampingan remaja puteri saat melalui masa pubertas dapat menjadi prioritas utama sekolah dan petugas kesehatan. Hal ini penting dilakukan dalam upaya peningkatan status kesehatan reproduksi remaja puteri di masa yang akan datang.

\section{UCAPAN TERIMAKASIH}

Penghargaan kami sampaikan kepada Sekolah Dasar Negeri (SDN) 05 Marunda, Cilincing, Jakarta Utara dan Puskesmas Rumah Susun (Rusunawa) Marunda, Cilincing, Jakarta Utara yang telah membantu dalam memfasilitasi tempat kegiatan Pengabdian Kepada Masyarakat. Penghormatan kami sampaikan pula kepada Fakultas Kedokteran dan Kesehatan Universitas Muhammadiyah Jakarta yang telah mendanai untuk kegiatan Pengabdian Kepada Masyarakat ini.

\section{DAFTAR RUJUKAN}

Aniebue, U. U., Aniebue, P. N. and Nwankwo, T. O. (2009) 'The impact of premenarcheal training on menstrual practices and hygiene of Nigerian school girls', Pan African Medical Journal, 2(1).

Crichton, J., Ibisomi, L. and Gyimah, S. O. (2012) 'Mother-daughter communication about sexual maturation, abstinence and unintended pregnancy: Experiences from an informal settlement in Nairobi, Kenya', Journal of Adolescence. Elsevier, 35(1), pp. 2130.

DKI Jakarta (2020) Puskesmas Rusun Marunda Cluster B Blok 8- JakartaDKI Jakarta. Available at: http://www.petalokasi.org.

Effendy, O. U. (2011) 'Ilmu Komunikasi Teori dan Praktek Cetakan ke-23', Bandung: PT. Remaja Rosdakarya.

KBBI Online (2021) Arti Kata IImiah-Kamus Besar Bahasa Indonesia (KBBI). Available at: http://kbbi.web.id.

Kinanti, S. (2009) 'Rahasia Pintar Wanita', Jogjakarta: Aulia publishing.

Lapau B (2012) Metode Penelitian Kesehatan: Metode IImiah Penulisan Skripsi, Tesis dan Disertasi. Jakarta: Yayasan Pustaka Obor Indonesia.

Mahat, S., Parajuli, K. and Pokhrel, B. (2020) 'Knowledge and practice regarding menstrual hygiene among physically disabled women in Kathmandu, Nepal', Journal of Karnali Academy of Health Sciences, 3(1), pp. 1-10.

Marván, M. L. and Molina-Abolnik, M. (2012) 'Mexican adolescents' experience of menarche and attitudes toward menstruation: role of communication between mothers and daughters', Journal of pediatric and adolescent 
gynecology. Elsevier, 25(6), pp. 358363.

Nugraheni, H. and Indarjo, S. (2018) Buku Ajar Promosi Kesehatan Berbasis Sekolah. Deepublish.

Nuryaningsih and Rosyati Heri (2020) 'Hubungan Sumber Informasi dengan pengetahuan personal hygiene saat menstruasi', Jurnal Penelitian Universitas Muhammadiyah Jakarta, 25(ISSN 0853-6007), pp. 63-71.

Wikipedia (2021) Marunda Cilincing Jakarta

Utara. Available at:

http://id.m.wikipedia.org. 